Article Type: Research Paper

\title{
Value Relevance of Asset Revaluation Disclosure
}

\author{
Yossi Diantimala ${ }^{1 *}$ and Hafiez Sofyani ${ }^{2}$
}

\begin{abstract}
:
Research aims: The paper aims to examine the value relevance of asset revaluation disclosure after seven years of implementation of international accounting standards (IAS). This paper highlights the implementation of SFAS 16 which is converged to IAS 16 regarding fixed assets. The SFAS 16 requires companies to disclose the value of fixed assets according to market values if the book value is significantly different from the market value.

Design/Methodology/Approach: We analyze 46 non-financial companies that employ the revaluation model during 2012-2018. As benchmarks, we randomly collect 46 non-financial companies that d0 not revaluate their assets during the period. To investigate the value relevance of upward asset revaluation disclosure, we approximate the relationship between and the effect of upward asset revaluation disclosure and stock price by employing Ohlson modified model (1995).
\end{abstract}

\section{*CORRESPONDENCE: \\ ydiantimala@unsyiah.ac.id}

THIS ARTICLE IS AVAILABLE IN:

http://journal.umy.ac.id/index.php/ai

DOI: 10.18196/jai.2103164

\section{CITATION:}

Diantimala, Y., \& Sofyani, H. (2020). Value Relevance of Asset Revaluation Disclosure. Journal of Accounting and Investment, 21(3), 555-569.

\section{ARTICLE HISTORY}

Received:

17 Jul 2020

Reviewed:

10 Aug 2020

15 Sep 2020

Revised:

18 Aug 2020

17 Sep 2020

Accepted:

17 Sep 2020
Research findings: We suggest that disclosure of upward asset revaluation is value-relevant. The SFAS 16 states that an upward asset revaluation increases the value of equity and assets. Furthermore, we suggest that the information of the book value of equity, net income, and earnings of asset revaluation firms is valuerelevant. The results show that the information of the book value of equity and earnings are more value-relevant than upward asset revaluation disclosure and net income.

Theoretical contribution/Originality: Our study contributes to filling the gap of previous results related to the value relevance of fair value disclosure of fixed assets.

Practitioner/Policy implication: This research gives an input for financial accounting standards development in Indonesia, particularly regarding the issue of asset revaluation.

Research limitation/Implication: Only 46 non-financial companies that employ the revaluation model during 2012-2018. Thus, our study has a small sample size. Keywords: Value relevance; fair value disclosure; revaluation model; fixed assets.

\section{Introduction}

One of the important issues governed by the financial standards is the implementation of fair value measurements that are believed to provide more relevant financial information so that accounting information is more useful in making business decisions and meeting investor expectation (McInnis, Yu, \& Yust, 2018; Hitz (2007). Many conflicting empirical results have emerged regarding the qualitative characteristics of financial information produced using fair value measurement. A growing opinion is a fair value for poverty, plant, and equipment values provide 


\section{Diantimala \& Sofyani \\ Value Relevance of Asset Revaluation Disclosure}

more meaningful information than the book value of assets (Gwilliam \& Jackson, 2008). Other scholars claim that asset values measured using fair value are more relevant than using other methods (Herrmann, Saudagaran, \& Thomas, 2006), but less reliable (Herrmann et al., 2006) since managers may use their discretion to manipulate the information (Lilien, Sarath, \& Yan, 2019). Earlier, Cotter and Zimmer (2003) provide empirical evidence for the adoption of fair value in Australia. They conclude that fixed assets that are measured by fair value are more reliable. The contradiction in Cotter and Zimmer (2003) results may be due to the period of data used before companies adopt IFRS mandatorily.

Besides, conflicting results occurred regarding the advantage of fair value information. Quagli and avallone (2010) show that fair value disclosure can reduce the difference between the market value to book value which reflects a lower information asymmetry. In the most recent period, Ruan (2019) finds that fair value for fixed assets provides more relevant information about fixed assets value for resale, however, and allowed impairment loss may contain a manager's opportunistic behavior which can reduce the benefits of information for investment decision making. Managers use an upward asset revaluation strategically to adjust fixed assets value to the value appropriate for sale. In line with Ruan (2019), Vergauwe and Gaeremynck (2019) show that the adoption of fair value measurement fails to reduce information asymmetry. This paper contributes to the literature related to the value relevance of disclosing and measuring the fair value of fixed assets after years of IFRS implementation in Indonesia.

Revaluation of fixed assets is a model based on fair value. Fixed assets whose fair value can be measured reliably are recorded at the revaluation amount, that is, the fair value at the revaluation date less accumulated depreciation and accumulated impairment losses after the revaluation date (Indonesian SFAS 16). SFAS 16 which is converged to IAS 16 requires companies to assess their assets after initial acquisition using the asset revaluation method and then disclose the asset value according to market value if the book value differs significantly from the market value. The company also records the value of the asset at the revaluation value in the financial statements. Therefore, the determination of the value of assets using the market value of assets affects the value of accounting earnings, the value of equity, and the value of a company's assets (Herrmann et al., 2006).

Besides, being able to produce highly relevant information, fair value measurement has a weakness to measure the value of assets that have no market value. The market value of some properties, plant, and equipment does not exist. If the market value of an asset is not available, the way to determine the value of fixed assets is using the appraisal, level 3 measurement in fair value hierarchy. The appraisal determines the market value of fixed assets that have no market value. In this case, the company is required to report the name of the appraisal conducting the assessment (SFAS 16). However, appraisal methods have some weaknesses, the validity of doubtful values (Sundgren, Mäki, \& Somoza-López, 2018), less reliable due to uncertain and bias measurement which are the main sources of information risk (Ayres, 2016). As a result, the resulting value is less credible and cannot be verified (Sundgren et al., 2018) thereby increasing the problem 


\section{Diantimala \& Sofyani \\ Value Relevance of Asset Revaluation Disclosure}

of adverse selection (Sundgren et al., 2018). Asset values can be manipulated according to company needs (Sundgren et al., 2018). Therefore, the market does not always respond positively to large amounts of disclosure of financial information (Vergauwe \& Gaeremynck, 2019). Sometimes, the market evaluates large disclosures with negative responses. Market participants have different views on fixed asset fair value information disclosed by companies. For market participants who are risk-takers, this condition is less influential on their decisions. Conversely, for risk-averse market players, this condition greatly affects their decisions. This paper contributes to the literature related to the meaning of fair value information in Indonesia.

This study examines whether fair value disclosure and measurement of fixed assets is value-relevant. Specifically, we examine whether fair value disclosure has a significant meaning for market participants after seven years of implementation of IFRS-based accounting standards in Indonesia. To investigate the value relevance of assets revaluation disclosure as a fair value-based model, we approximate the relationship between revaluation of fixed assets and stock price and the effect of revaluation of fixed assets on stock price using a modified model of Ohlson (1995) which has been extensively applied in the literature. We collect the data of non-financial firms listed in the Indonesian Stock Exchange for the period 2012-2018. The year 2012 is the first year to mandatorily implement IFRS-based standards in Indonesia. The year 2018 is cut off determined in this study for the last achievement of the implementation of IFRS-based standards. This study focuses on non-financial companies because the value relevance of fair value information differs between financial and non-financial companies (Mclnnis et al., 2018). For financial companies such as banks, the valuation of assets with fair value is no more relevant than historical cost (Mclnnis et al., 2018). To avoid sample bias, this research focuses on non-financial companies only. To test the hypothesis, we employ multivariate analysis. The empirical results of our study make an important contribution to the question as to whether fair value information of fixed assets is value relevance in Indonesian listed companies. The results are not consistent with our expectations that fixed assets revaluation as a base model of fair value is value relevance.

Our study contributes to filling the gap of previous results related to value relevance of fair value disclosure of fixed assets that are still getting minimal attention by academics today (Fathmaningrum \& Yudhanto, 2019; Israeli, 2015). Prior empirical research on fair value measurement is mostly limited to financial instruments (Mclnnis et al., 2018; Pascayanti, Rahman, \& Andayani, 2017; Song, 2015; Song, Thomas, \& Yi, 2010; Hassan, Percy, \& Stewart, 2006). The results support the value relevance of fair value disclosure of financial instrument information. All studies focus on financial sector firms. At the other side, most literature regarding fair value disclosure investigates the factors influencing the companies' decision to revalue their fixed asset in non-financial companies (latridis \& Kilirgiotis, 2012; Quagli \& Avallone, 2010; (Missonier-Piera, 2007); (Lin \& Peasnell, 2000); (Brown, Izan, \& Loh, 1992). The results are mixed. Testing on the effect of asset revaluation on stock prices has been done before by using old data (Cotter \& Zimmer, 2003; Aboody, Barth, \& Kasznik, 1999; Sharpe \& Walker, 1975). 


\author{
Diantimala \& Sofyani \\ Value Relevance of Asset Revaluation Disclosure
}

This paper provides insight into the issue of value relevance after IFRS adoption as a reference for financial reporting in the context of developing countries, namely Indonesia. Practically, this research provides input for financial accounting standards setter in Indonesia for the issue of asset revaluation in particular. The rest of our paper is organized as follows. In section 2 presents a literature review and hypothesis development. In section 3, we present the research method consisted of the data and sample, and analysis method. Section 4 represents the empirical results. In section 5, we present a summary and conclusions.

\title{
Literature Review and Hypotheses Development
}

\section{Upward Assets Revaluation of Fixed Assets}

The fair value concept is a term in accounting standards where assets and liabilities are recorded in the financial statements based on market value (Hitz, 2007). The application of fair value expects users of financial statements to get a more realistic picture of the amount recorded on the balance sheet because it has been adjusted to market conditions prevailing at the reporting date (mark to market) (Laux \& Leuz, 2010). Using mark-to-market accounting generates continual changes to the company's financial statements when the value of assets increases and decreases as profits and losses are recorded (Laux \& Leuz, 2010). Consequently, it is difficult to ascertain whether profits and losses are due to business decisions made by management or due to changes in the market. Another problem arises when re-measuring the value of assets based on market prices. Fixed assets that have no market value are revalued using a level 3 fair value hierarchy that contains validity and reliability weaknesses (Ayres, 2016). Appraisal as value-determining parties may have no uniformity of guidance. It makes the revalued value of assets difficult to verify so they are less reliable.

Asset revaluation is an adjustment of the value of an asset to its market value. Revaluations affect the book value of an individual asset for the current price and the book value of the owner's equity (net assets) for the real value given by the capital market (Saito, 1983). Asset revaluation causes total assets to increase (upward assets revaluation) or decrease (downward assets revaluation). Incentives for upward assets revaluation or downward assets revaluation may differ among firms. Upward assets revaluation is more favored by the company because it reveals the direct cost and the real value of the company's fixed assets to investors (Missonier-Piera, 2007), increase the value of assets and display better financial conditions (latridis \& Kilirgiotis, 2012), increase future firm performance (Aboody et al., 1999), and cover equity reduction and poor liquidity (Lin \& Peasnell, 2000). Conversely, one of the reasons for companies to perform downward asset revaluation is a political cost (Quagli \& Avallone, 2010).

Specific for the Indonesian case, the obligation to disclose fair value measurements is regulated in Indonesian SFAS 68 which has been converted to IFRS 13. SFAS 68 relates to SFAS 16 in terms of measurement of fair value for fixed assets. Revaluation of fixed assets is a model based on fair value. Based on SFAS 16 which is converged to IAS 16, 
stated that fixed assets whose fair value can be measured reliably are recorded at the revaluation amount, that is, the fair value at the revaluation date less accumulated depreciation and accumulated impairment losses after the revaluation date. Companies are required to assess their assets after initial acquisition using the asset revaluation method and then disclose the asset value according to market value if the book value differs significantly from the market value. The company only discloses in Notes to Financial Statements but does not record it in the financial statements if the company applies the cost model. If the company applies a revaluation model, in addition to disclosing the market value of assets, the company also records the value of the asset at the revaluation value in the financial statements. Therefore, the determination of the value of assets using the market value of assets affects the value of accounting earnings, the value of equity, and the value of a company's assets.

According to SFAS 16, if the value of assets after revaluation increases, a company records the value of the increase of the difference in market value and book value in two conditions: (1) recognizing the increase in the income statement as other benefits outside the post other comprehensive income. This recognition is made only in the year when the asset revaluation occurs. (2) Recognize the increase in assets due to revaluation as other comprehensive income and accumulated in equity as a post revaluation surplus. This post will continue to be reported and disclosed as long as the company still owns the asset and will stop reporting when the fixed asset is released (Herrmann et al., 2006).

\section{Value Relevance of Upward Assets Revaluation Disclosure}

Public companies, ideally, disclose financial information that is favorable to the market to reduce information asymmetry. However, in reality, the company prefers to disclose unfavorable financial information disclosures so that the information asymmetry remains high (Bertomeu \& Magee, 2015). The market response is under the information conveyed by the company. Largely unfavorable information disclosure does not increase stock prices (Bertomeu \& Magee, 2015). Upward fair value disclosure is favorable information that is reflected in the high market response to the value of assets that have been revalued (McInnis et al., 2018).

Sharpe and Walker (1975) demonstrate that firm choice to upward assets revaluation changes the stock price. Aboody et al. (1999) strengthen Sharpe and Walker (1975) that assets revaluation has a positive relationship with a stock return by UK firms. Some further empirical evidence supports that theory. Cotter and Zimmer (2003) demonstrate that upward asset revaluation disclosure of fixed assets of non-financial industries in Australia is value relevance. Israeli (2015) examines the value relevance of upward fixed assets revaluation of some countries in the world (world scope). The results are consistent with (Cotter \& Zimmer, 2003) that upward fixed assets revaluation has a higher value relevance. Fathmaningrum and Yudhanto (2019) and Pascayanti et al. (2017) provide evidence from Indonesia. Fathmaningrum and Yudhanto (2019) examine market reaction on fixed assets revaluation of manufacturing companies in Indonesia for the period 2015-2016. However, they do not mention specifically upward assets 


\section{Diantimala \& Sofyani \\ Value Relevance of Asset Revaluation Disclosure}

revaluation or downward assets revaluation. They find the revaluation of that fixed asset positively significantly affects the market reaction.

The other previous studies that examine the value relevance of fair value information of financial companies especially show inconsistent results. (McInnis et al., 2018) investigate the value relevance of U.S. banking for the period 1996-2013. The results show that the combined value relevance of book value of equity and income based on fair value is less than that based on GAAP. Fair value income is less value-relevant than GAAP income. The book value of equity under fair value is not more value-relevant than under GAAP. Overall, their results suggest that financial information under fair value accounting is not more relevant for bank valuation than financial information under current GAAP. Hassan et al. (2006) examine the fair value of financial instruments of banking in Australia and find that fair value information of financial instruments is not value-relevant. Pascayanti et al. (2017) investigate the value relevance of fair value information of assets and liabilities of banking listed in the Indonesia Stock Exchange for the period 2012-2014. They find that fair value information of assets and liabilities is value-relevant. Song (2015) examines empirically the effects of market volatility on the value relevance of fair value information of U.S. financial companies for the period of 2008 to 2013 . He finds that fair values are highly value-relevant when market volatility is high.

$\boldsymbol{H}_{1}$ : Upward fixed asset revaluation in Indonesia is value-relevant.

$\boldsymbol{H}_{2}$ : The information of the book value of equity, net income, and earnings of asset revaluation firms are more value-relevant than them of non-asset revaluation firms.

\section{Research Method}

\section{Sample and Sampling Technique}

This paper examines the value relevance of fair value disclosure after seven years of implementation of IFRS in Indonesia. The sample is non-financial firms listed in the Indonesian Stock Exchange for the period 2012-2018. This study focuses on nonfinancial companies because the value relevance of fair value information differs between financial and non-financial companies (McInnis et al., 2018). For financial companies such as banks, the valuation of assets with fair value is no more relevant than historical cost (Mclnnis et al., 2018). To avoid sample bias, this research focuses on nonfinancial companies only (latridis \& Kilirgiotis, 2012; Missonier-Piera, 2007; (Lin \& Peasnell, 2000). As Lin and Peasnell, 2000), this study divide the sample into two groups. The first group is the companies that disclose the information of fixed assets revaluation. The second group is the companies that do not disclose the information of fixed assets revaluation as benchmarking companies. We take the proportional number of companies in each of these groups. 46 non-financial companies employ the revaluation model during 2012-2018. As benchmarks, we randomly pick 46 non-financial companies that did not reevaluate their assets during the period. 


\author{
Diantimala \& Sofyani \\ Value Relevance of Asset Revaluation Disclosure
}

\title{
Variables Measurement
}

To test the value relevance of fair value information, we use the modified Ohlson model (1995). The dependent variable used in the model is the share price. Upward assets revaluation, the book value of equity, net income, and earnings (operating income) are independent variables. Share price $\left(\mathrm{SP}_{\mathrm{it}}\right)$ is measured by using the value of the next period share price. The current period's financial information is published in the following year. For example, if a company revalues assets in 2013, the share price used will be the share price in 2014. Upward assets revaluation (UAR it) is measured by the upward value of fixed assets revalued and reported in the current period income statement. Book value of equity $\left(\mathrm{BVE}_{\mathrm{it}}\right)$ is the total value of equity reported in the statement of financial position changes. Net income $\left(\mathrm{Nl}_{i t}\right)$ is measured by total net income after tax as reported in the income statement. Earnings $\left(E_{i t}\right)$ are measured by total operating income (earnings before interest and tax) as reported in the income statement.

\section{Analysis Method}

To investigate value relevance of upward asset revaluation disclosure, the book value of equity, net income, and earnings, we approximate the relationship between upward asset revaluation disclosure, the book value of equity, net income, earnings, and stock price and the effect of upward asset revaluation disclosure, the book value of equity, net income, and earnings on the stock price. We employ Ohlson modified model (1995) which has been extensively applied in the literature to examine the value relevance. This study occupies Mclnnis et al. (2018) ways to examine the hypothesis by separating the model for companies that revaluate fixed assets and those that do not revaluate assets. The model used is as follows:

$$
\begin{aligned}
& S P \_A R F_{i t}=\alpha_{0}+\alpha_{1} U A R \_A R F_{i t}+\alpha_{2} B V E \_A R F_{i t}+\alpha_{3} N_{-}{ }_{2} A R F_{i t}+\alpha_{4} E_{-} A R F_{i t}+\varepsilon_{i} \ldots \text { (1) } \\
& \text { SP_NonARF } F_{i t}=\alpha_{0}+\alpha_{1} \text { BVE_NonARF }_{i t}+\alpha_{2} N_{-} \text {NonARFV }_{i t}+\alpha_{3} E_{-} \text {NonARF }_{i t}+\varepsilon_{\mathrm{i}}
\end{aligned}
$$

Where:

SP_ARF $F_{i t}$ is share price of firm $i$ with assets revaluation for period $t$; UAR_ARF $F_{i t}$ is upward assets revaluation of firm $i$ with assets revaluation for period t; BVE_ARF it is book value of equity of firm $i$ with assets revaluation for period $t$; NI_ARFV $V_{i t}$ is net income of firm $i$ with assets revaluation for period $t$; $E_{-} A R F_{i t}$ is earnings of firm $i$ with assets revaluation for period t. NonARF is non assets revaluation firm.

\section{Additional Analysis}

To support Fathmaningrum and Yudhanto (2019), whether asset revaluation information value relevance or not for the period 2012-2018 in Indonesia, this study combines the non-asset revaluation firms and asset revaluation firms by using a dummy variable. 1 for assets revaluation information from assets revaluation firms and 0 for otherwise. The model to capture the value relevance of assets revaluation information is as follows: 


$$
S P_{i t}=\beta_{0}+\beta_{1} U A R \_N U A R_{i t}+\beta_{2} B V E_{i t}+\beta_{3} N I_{i t}+\beta_{4} E_{i t}+\varepsilon_{i} \ldots . . \text { (3) }
$$

Where, $\mathrm{SP}_{\text {it }}$ is the share price of firm i for period t; UAR_NUAR $R_{i t}$ is assets revaluation and non-assets revaluation disclosure of firm $i$ for period $t$; $B V E_{i t}$ is book value of equity of firm $\mathrm{i}$ for period $\mathrm{t}$; $\mathrm{Nl}_{\text {it }}$ is net income of firm $\mathrm{i}$ for period $\mathrm{t}$; $\mathrm{E}_{\mathrm{it}}$ is earnings of firm $\mathrm{i}$ for period $t$.

\section{Result and Discussion}

\section{Descriptive Statistics}

Table 1 presents descriptive statistics for all variables employed for investigating hypothesis 1. A total of 92 firms-years observations from 2012 to 2018 are employed to test the hypothesis. The average share price for models 1 and 2 is quite different. IDR 1,190 compared to IDR 3,170. The maximum and minimum gap values either in model 1 or in model 2 are high. In model 1 , the highest share price of assets revaluation firms is 11,900 and the lowest is 50 rupiah. In model 2, the highest share price of non-assets revaluation firms is 52,100 rupiah and the lowest is 80 rupiah. The average share price of both asset revaluation and non-asset revaluation in model 3 is relatively moderate, 2,180 rupiahs. Specific for upward assets revaluation, the average value of upward assets revaluation is 1.44 trillion rupiahs. The gap between the maximum and minimum value of assets revaluation is reasonably high. The highest assets revaluation value is 10.47 trillion rupiahs, and the lowest is 0.00 trillion rupiahs. It indicates that assets revaluation firms adjust the value of assets to reasonable fair value (latridis \& Kilirgiotis, 2012; (Lin \& Peasnell, 2000).

The average book value of equity in models 1 and 2 is slightly different. However, the gap between the maximum and minimum values in the two models is extremely high. In model 1 , the highest value of book value of equity of asset revaluation firms is 41.65 trillion rupiahs and the lowest value is -0.14 trillion rupiahs. In model 2 , the highest book value of equity of non-assets revaluation is 89.81 trillion rupiahs, and the lowest is -0.2 trillion rupiahs. Especially for net income and earnings, the average net income and earnings of assets revaluation firms are lower than non-assets revaluation firms. The gap of maximum and minimum value of net income of assets revaluation firms is low. It indicates that the characteristic of net income and earnings of assets revaluation firms is almost the same. As much as $28.26 \%$ of assets revaluation firms experienced a loss in the year of asset revaluation. Net loss is one of the reasons companies reevaluate their assets (Lin \& Peasnell, 2000).

Model 3 is an additional analysis to examine the value relevance of assets revaluation disclosure by combining upward assets revaluation and non-asset revaluation. We use a dummy variable, 1 for assets revaluation information, and 0 for otherwise. The average share price of all observation is 2,180 rupiah. 
Diantimala \& Sofyani

Value Relevance of Asset Revaluation Disclosure

Table 1 Descriptive statistics for variables used in the model (1), (2), and (3)

\begin{tabular}{|c|c|c|c|c|c|c|}
\hline $\begin{array}{c}\text { Model } \\
s\end{array}$ & $\begin{array}{l}\text { Statistics } \\
\text { Indicators }\end{array}$ & $\begin{array}{r}\text { SP (in thousand } \\
\text { rupiahs) }\end{array}$ & $\begin{array}{l}\text { UAR (in trillion } \\
\text { rupiahs) }\end{array}$ & $\begin{array}{l}\text { BVE (in trillion } \\
\text { rupiahs) }\end{array}$ & $\begin{array}{r}\text { NI (in trillion } \\
\text { rupiahs) }\end{array}$ & $\begin{array}{l}\text { E (in trillion } \\
\text { rupiahs) }\end{array}$ \\
\hline \multirow{6}{*}{$\begin{array}{l}\text { Model } \\
1\end{array}$} & Mean & 1.19 & 1.44 & 3.11 & 0.11 & 0.26 \\
\hline & Median & 0.53 & 0.35 & 0.33 & 0.02 & 0.04 \\
\hline & Maximum & 11.96 & 10.47 & 41.65 & 2.17 & 3.98 \\
\hline & Minimum & 0.05 & 0.00 & -0.14 & -1.54 & -1.76 \\
\hline & Std. Dev. & 2.17 & 2.53 & 7.46 & 0.62 & 0.88 \\
\hline & Observations & 46 & 46 & 46 & 46 & 46 \\
\hline \multirow{6}{*}{$\begin{array}{l}\text { Model } \\
2\end{array}$} & Mean & 3.17 & - & 5.43 & 1.03 & 1.47 \\
\hline & Median & 0.92 & - & 0.66 & 0.10 & 0.17 \\
\hline & Maximum & 52.10 & - & 89.81 & 22.74 & 27.90 \\
\hline & Minimum & 0.08 & - & -0.20 & -1.86 & -0.76 \\
\hline & Std. Dev. & 8.01 & - & 15.08 & 3.50 & 4.37 \\
\hline & Observations & 46 & - & 46 & 46 & 46 \\
\hline \multirow{6}{*}{$\begin{array}{l}\text { Model } \\
3\end{array}$} & Mean & 2.18 & 0.50 & 4.27 & 0.57 & 0.87 \\
\hline & Median & 0.61 & 0.50 & 0.51 & 0.04 & 0.08 \\
\hline & Maximum & 52.10 & 1.00 & 89.81 & 22.74 & 27.90 \\
\hline & Minimum & 0.05 & 0.00 & -0.20 & -1.86 & -1.76 \\
\hline & Std. Dev. & 5.92 & 0.50 & 11.89 & 2.55 & 3.20 \\
\hline & Observations & 92 & 92 & 92 & 92 & 92 \\
\hline
\end{tabular}

SP refers to share price; UAR is upward assets revaluation; $\mathrm{BVE}, \mathrm{NI}$, and $\mathrm{E}$ stand for the book value of equity, net income, and earnings respectively. The share price is shown in a thousand rupiahs. $\mathrm{BVE}, \mathrm{NI}$, and $\mathrm{E}$ display in trillion rupiahs. The sample companies for models 1 and 2 are different. Model 1 is for assets revaluation firms, and model 2 is for non-assets revaluation firms.

Table 2 Pearson correlation coefficient for all variables used in the model (1) and (2)

\begin{tabular}{|c|c|c|c|c|c|c|}
\hline Models & Variables & Stat. Indic. & SP & UAR & BVE & NI \\
\hline \multirow[t]{8}{*}{ Model 1} & UAR & Correlation & $(0.15)$ & & & \\
\hline & & t-Statistic & $(0.98)$ & & & \\
\hline & BVE & Correlation & 0.38 & $(0.13)$ & & \\
\hline & & t-Statistic & $2.70 * * *$ & $(0.88)$ & & \\
\hline & $\mathrm{NI}$ & Correlation & 0.50 & $(0.06)$ & $(0.16)$ & \\
\hline & & t-Statistic & $3.80 * * *$ & $(0.38)$ & (1.09) & \\
\hline & $\mathrm{E}$ & Correlation & 0.66 & $(0.14)$ & 0.06 & 0.91 \\
\hline & & t-Statistic & $5.75 * * *$ & $(0.96)$ & 0.43 & $14.79 * * *$ \\
\hline \multirow[t]{6}{*}{ Model 2} & BVE & Correlation & 0.36 & & & \\
\hline & & t-Statistic & $2.55 * * *$ & & & \\
\hline & $\mathrm{NI}$ & Correlation & 0.30 & & 0.95 & \\
\hline & & t-Statistic & $2.05 * *$ & & $19.74 * * *$ & \\
\hline & $E$ & Correlation & 0.36 & & 0.96 & 0.99 \\
\hline & & t-Statistic & $2.52 * *$ & & $23.69 * * *$ & $45.44 * * *$ \\
\hline \multirow[t]{8}{*}{ Model 3} & AR & Correlation & $(0.17)$ & & & \\
\hline & & t-Statistic & (1.61) & & & \\
\hline & BVE & Correlation & 0.36 & $(0.10)$ & & \\
\hline & & t-Statistic & $3.70 * * *$ & $(0.94)$ & & \\
\hline & $\mathrm{NI}$ & Correlation & 0.32 & $(0.18)$ & 0.82 & \\
\hline & & t-Statistic & $3.26 * * *$ & $-1.76^{*}$ & $13.81 * * *$ & \\
\hline & $E$ & Correlation & 0.39 & (0.19) & 0.85 & 0.99 \\
\hline & & t-Statistic & $4.02 * * *$ & $-1.84^{*}$ & $15.35 * * *$ & $58.22 * * *$ \\
\hline
\end{tabular}

SP refers to share price; UAR is upward assets revaluation; $\mathrm{BVE}, \mathrm{NI}$, and $\mathrm{E}$ stand for book value of equity, net income, and earnings respectively. $* * *, * *, *$ denotes a significance level of $1 \%, 5 \%$, and $10 \%$ respectively.

The Pearson correlations among independent variables in the models of Equation (1), (2), and (3) are presented in Table 2. It shows that most of the variables of interest are significantly correlated at $1 \%, 5 \%$, and $10 \%$ level. However, some variables have low 
correlations; thus, it is not potential problems for our results. Model 1 presents that upward assets revaluation has a positively weak relationship with the book value of equity, net income, and earnings. The relationship between the book value of equity and net income and between the book value of equity and earnings are weak. However, the correlation between net income and earnings is positively significant at $1 \%$ level. Model 3 represent also a weak relationship between assets revaluation and the book value of equity, net income, and earnings. In model 2 we show that all variables are significantly correlated at the level of $1 \%$ and $5 \%$.

\section{Main Results}

We examine the value relevance of upward assets revaluation disclosure in Indonesia for the period 2012-2018. We investigate also the value relevance of book value of equity, net income, and earnings of asset revaluation firms. The multiple regression results are presented in Table 3 . We suggest that the information of upward asset revaluation in Indonesia is value-relevant to support the results of Fathmaningrum and Yudhanto (2019) and Pascayanti et al. (2017).

Based on Model 1 in Table 3, shows that upward assets revaluation is negatively related to stock price. However, the effect is not significant (coefficient $=-2.3664$, t-stat. $=$ 0.0118). The result indicates that the information of upward assets revaluation is not essential information for the market. The results do not succeed to support the hypothesis $\left(\mathrm{H}_{1}\right)$ and contradict with the results of the previous result by Fathmaningrum and Yudhanto (2019), Israeli (2015), Cotter and Zimmer (2003), Aboody, et al. (1999), and Sharpe and Walker (1975). This result is not following our expectation that asset revaluation disclosure is value-relevant and it is getting higher after seven years of implementation of IFRS in Indonesia.

The result could be an indication that upward asset revaluation disclosure is not useful to an investor in making a business decision. The results are consistent with Vergauwe and Gaeremynck (2019) that fair value disclosure is not important information for market participants so the share price does not change significantly when this information is conveyed to the public. The benefit from disclosing information on asset revaluation could be less considered by investors because there is an indication that upward asset revaluation, especially for fixed assets that have no market value, is used by managers to conceal companies' bad financial performance (Lilien, et al., 2019). By using upward asset revaluation, negative net income can be covered by positive and higher asset revaluation of the fixed asset so that it looks more profitable comprehensive income.

For fixed assets that have no market value, its market value is determined by the appraiser. Appraisal methods have some weaknesses, the validity of doubtful values (Sundgren et al., 2018), less reliable due to uncertain and bias measurements which are the main sources of information risk (Ayres, 2016). The market participants are aware of the condition. As a result, the resulting value is less credible and cannot be verified (Sundgren et al., 2018) thereby increasing the problem of adverse selection (Sundgren 
et al., 2018). Asset values can be manipulated according to company needs (Sundgren et al., 2018). Therefore, the market does not always respond positively to large amounts of disclosure of financial information (Vergauwe \& Gaeremynck, 2019). Sometimes the market evaluates large disclosures with negative responses. Market participants have different views on fixed asset fair value information disclosed by companies. For market participants who are risk-takers, this condition is less influential on their decisions. Conversely, for risk-averse market players, this condition greatly affects their decisions.

As SFAS 16 state that asset revaluation affects total equity and assets. We suggest that the book value of equity, net income, and earnings of asset revaluation firms are value relevance. The results show that net income is negatively related to stock price. The same as the results of the testing of upward asset revaluation, the effect of net income on share price is not significant. Both upward assets revaluation and net income are not value-relevant. The other main information, the book value of equity and earnings of asset revaluation firms positively significantly affects share price at $5 \%$ and $1 \%$ level of significance respectively. It indicates that the Book value of equity and earnings of asset revaluation firms provide more useful information for users. Both the book value of equity and earnings are value-relevant.

In model 2, net income and earnings of non-assets revaluation firms affect share price at a $1 \%$ level of significance. It indicates that net income and earnings of non-asset revaluation firms are more value relevance than the book value of equity for non-assets revaluation firms. Based on Model 3 in Table 3, we provide the information on upward assets revaluation negatively affects share price but insignificant (coefficient = 1003.151, t-stat. $=-0.9228$ ).

Table 3 Statistic indicators of all variables for Model (1), (2), and (3)

\begin{tabular}{llrrr}
\hline Variables & Stat. Indic. & Model 1 & Model 2 & Model 3 \\
\hline UAR & Coefficient & -2.3664 & & -1003.1510 \\
& t-Statistic & -0.0118 & & -0.9228 \\
BVE & Coefficient & $0.0001^{* *}$ & 0.0000 & 0.0000 \\
& t-Statistic & 2.2896 & 0.0887 & 0.0426 \\
NI & Coefficient & -0.0008 & $-0.0061^{* * *}$ & $-0.0053^{* * *}$ \\
& t-Statistic & -0.7234 & -2.8990 & -4.0361 \\
E & Coefficient & $0.0021^{* * *}$ & $0.0054^{* * *}$ & $0.0049^{* * *}$ \\
& t-Statistic & 2.7394 & 2.7167 & 4.2779 \\
C & Coefficient & 506.2464 & 1379.9160 & 1481.6590 \\
& t-Statistic & 0.2185 & 1.2113 & 1.8393 \\
Stat. Indic. & R-squared & 0.5481 & 0.2749 & 0.2979 \\
& Adjusted R-squared & 0.5040 & 0.2231 & 0.2656 \\
& F-statistic & 12.4304 & 5.3067 & 9.2269 \\
& Prob(F-statistic) & 0.0000 & 0.0034 & 0.0000 \\
& Durbin-Watson stat & 1.8679 & 1.7679 & 1.8074 \\
\hline
\end{tabular}

SP refers to share price; UAR is upward assets revaluation; $\mathrm{BVE}, \mathrm{NI}$, and $\mathrm{E}$ stand for the book value of equity, net income, and earnings respectively. $* * *, * *, *$ denotes a significance level of $1 \%, 5 \%$, and $10 \%$ respectively. 


\author{
Diantimala \& Sofyani \\ Value Relevance of Asset Revaluation Disclosure
}

It indicates that the information of upward assets revaluation is not value relevance. These results reinforce the results in Model 1 that upward asset revaluation is not value relevance.

Based on the results, we conclude that after seven years of implementation of IFRS in Indonesia, financial statement users still consider that the book value of equity and earnings is more important information than fair value disclosure of fixed assets. The book value of the fixed asset is still very important information for investors cause of its high reliability. The book value of assets can be traced reliably. Meanwhile, the fair value of fixed assets suspected of containing the discretion of the manager. Fair value information is relevant but less reliable (Herrmann et al., 2006). Users know that the measurement of a fixed asset that has no market value by using level 3 hierarchy contains many weaknesses so it is less reliable (Ayres, 2016; Song et al., 2010). The resulting financial information is more uncertain (Ayres, 2016). Fair value measurement can be a company's vehicle to manage their earnings (Lilien, et al., 2019; Hsu \& Lin, 2016). Users feel the use of fair value that increases the value of comprehensive income and assets is a way for companies to mislead the company's financial information so that the company's financial condition looks good (Vergauwe \& Gaeremynck, 2019). Fair value measurement could be noisier and less precise simply due to the subjectivity nature of the appraisal (Ayres, 2016). Level three measurements are thus subject to greater information asymmetry than are level one and two measurements (Vergauwe \& Gaeremynck, 2019; Song et al., 2010).

\title{
Conclusion
}

We examine the value relevance of asset revaluation disclosure after seven years of implementation of international accounting standards. The spirit of implementing international standards is the functioning of fair values measurement that are believed to provide more relevant financial information. However, the application of fair value for assets that have no market value contains many weaknesses so it is less reliable. Almost all types of fixed assets have no market value. Using a level three fair value hierarchy contains validity and reliability weaknesses to re-measure the value of fixed assets. This causes the value of fixed assets to be less reliable, although highly relevant.

This paper highlights the implementation of SFAS 16 which is converged to IAS 16 regarding fixed assets. SFAS 16 requires companies to disclose the value of fixed assets according to market values if the book value is significantly different from the market value. Revaluation of fixed assets is a model based on fair value. We analysis 46 nonfinancial companies that employ the revaluation model during 2012-2018. As benchmarks, we randomly collect 46 non-financial companies that did not reevaluate their assets during the period. We suggest that disclosure of upward asset revaluation is value relevance. The results show that upward assets revaluation is negatively related to stock price. However, the effect is not significant. The result indicates that the information on upward assets revaluation is not essential information for the market. 
The results do not support the hypothesis $\left(\mathrm{H}_{1}\right)$ and contradict the results of the previous result.

As SFAS 16 state that asset revaluation affects total equity and assets. We suggest that the book value of equity, net income, and earnings of asset revaluation firms are valuerelevant. The results show that net income is negatively related to stock price. The same as the results of the testing of upward asset revaluation, the effect of net income on share price is not significant. Both upward assets revaluation and net income are not value-relevant. The other main information, book value of equity and earnings of asset revaluation firms positively significantly affect the share price. It indicates that the Book value of equity and earnings of asset revaluation firms provide more useful information for users. Both the book value of equity and earnings are value relevance. The results support the hypothesis $\left(\mathrm{H}_{2}\right)$.

This study is subject to several limitations. First, we use a small sample size of all nonfinancial firms listed in the Indonesia stock exchange due to only 46 non-financial companies that employ the revaluation model during 2012-2018. Further studies may combine non-financial firms with financial firms as well as lengthen the time of observation to capture a comprehensive feature of firms with asset revaluation disclosure. Second, we observe fair value disclosure by using the information and value reported in the income statements, the statements of financial position, and the notes of financial statements. We are unable to deeply explore the measurement method for each fixed asset components. Further studies may specify the level of fair value measurement of each fixed asset component to capture the level of fair value measurement which is not value-relevant. Third, we focus on upward asset revaluation only. Further studies may focus on upward and/or downward asset revaluation.

\section{References}

Aboody, D., Barth.M.E., Kasznik, R. (1999). Reevaluation of fixed assets and future firm performance: evidence from U.k. Journal of Accounting and Economics, 26(1-3), 149-178. https://doi.org/10.1016/s0165-4101(98)00040-8

Ayres, D. R. (2016). Fair value disclosures of level three assets and credit ratings. Journal of Accounting and Public Policy, 35(6), 635-653. https://doi.org/10.1016/j.jaccpubpol.2016.08.002

Bertomeu, J., \& Magee, R. P. (2015). Mandatory disclosure and asymmetry in financial reporting. Journal of Accounting and Economics, 59(2-3), 284-299. Retrieved from https://www.scholars.northwestern.edu/en/publications/mandatory-disclosure-andasymmetry-in-financial-reporting

Brown, P., Izan, H. Y., \& Loh, A. L. (1992). Fixed Asset Revaluations and Managerial Incentives. Abacus, 28(1), 36-57. https://doi.org/10.1111/j.1467-6281.1992.tb00268.x

Cotter, J., \& Zimmer, I. (2003). Disclosure Versus Recognition: The Case of Asset Revaluations. Asia-Pacific Journal of Accounting \& Economics, 10(1), 81-99. https://doi.org/10.2139/ssm.387641

Fathmaningrum, E. S., \& Yudhanto, S. K. (2019). Determinants of Fixed Asset Revaluation Decision and Its Impacts on Market Reaction: A Comparative Study in Indonesia and 
Singapore. Journal of Accounting and Investment, 20(2), 76-98. https://doi.org/10.18196/jai.2002118

Gwilliam, D., \& Jackson, R. H. G. (2008). Fair value in financial reporting: Problems and pitfalls in practice. A case study analysis of the use of fair valuation at Enron. Accounting Forum, 32(3), 240-259. https://doi.org/10.1016/j.accfor.2008.01.003

Hassan, M. S., Percy, M., \& Stewart, J. (2006). The value relevance of fair value disclosures in Australian firms in the extractive industries. Asian Academy of Management Journal of Accounting and Finance, 2(1), 41-61. https:// doi.org/10.22495/cocv4i2c2p2

Herrmann, D., Saudagaran, S. M., \& Thomas, W. B. (2006). The quality of fair value measures for property, plant, and equipment. Accounting Forum, 30(1), 43-59. https://doi.org/10.1016/j.accfor.2005.09.001

Hitz, J. M. (2007). The decision usefulness of fair value accounting - A theoretical perspective. European Accounting Review, 16(2), 323-362. https://doi.org/10.1080/09638180701390974

Hsu, P., \& Lin, Y. (2016). Fair Value Accounting and Earnings Management. Eurasian Journal of Business and Management, 4(2), 41-54. https://doi.org/10.15604/ejbm.2016.04.02.004

Iatridis, G. E., \& Kilirgiotis, G. (2012). Incentives for fixed asset revaluations: The UK evidence. Journal of Applied Accounting Research, 13(1), 5-20. https://doi.org/10.1108/09675421211231871

Israeli, D. (2015). Recognition versus disclosure: evidence from the fair value of investment property. Review of Accounting Studies, 20(4), 1457-1503. https://doi.org/10.1007/s11142-015-9335-x

Laux, C., \& Leuz, C. (2010). Did fair-value accounting contribute to the financial crisis? Journal of Economic Perspectives, 24(1), 93-118. https://doi.org/10.1257/jep.24.1.93

Lilien, S. B., Sarath, B. S., \& Yan, Y. (2019). Fair Value Accounting, Earnings Management, and the Case of Bargain Purchase Gain. Asian Review of Accounting, 28(2), 229-253. https://doi.org/10.2139/ssrn.3167597

Lin, Y. C., \& Peasnell, K. V. (2000). Fixed asset revaluation and equity depletion in the UK. Journal of Business Finance and Accounting, 27(3-4), 359-394. https://doi.org/10.1111/1468-5957.00317

McInnis, J. M., Yu, Y., \& Yust, C. G. (2018). Does fair value accounting provide more useful financial statements than current GAAP for banks? Accounting Review, 93(6), 257-279. https://doi.org/10.2308/accr-52007

Missonier-Piera, F. (2007). Motives for fixed-asset revaluation: An empirical analysis with Swiss data. International Journal of Accounting, 42(2), 186-205. https://doi.org/10.1016/i.intacc.2007.04.006

Ohlson, A. J. (1995). Earnings, Book Values, and Dividends in Equity Valuation. Contemporary Accounting Research, 11(2), 661-687. https://doi.org/10.1111/j.19113846.1995.tb00461.x

Pascayanti, Y., Rahman, A. F., \& Andayani, W. (2017). Relevansi Nilai Atas Nilai Wajar Aset dan Liabilitas Dengan Mekanisme Good Corporate Governance Sebagai Variabel Pemoderasi. InFestasi, 13(1), 227-242. https://doi.org/10.21107/infestasi.v13i1.3045

Quagli, A., \& Avallone, F. (2010). Fair value or cost model? Drivers of choice for IAS 40 in the real estate industry. European Accounting Review, 19(3), 461-493. https://doi.org/10.1080/09638180.2010.496547

Ruan, L. (2019). Accounting for Fixed Assets and Investment Efficiency: A Real Options Framework. Accounting and Business Research, 50(3), 238-268. https://doi.org/10.1080/00014788.2019.1675492 


\section{Diantimala \& Sofyani}

Value Relevance of Asset Revaluation Disclosure

Saito, S. (1983). Academy of Accounting Historians Asset Revaluation and Cost Basis:

Capital Revaluation in Corporate Financial Asset. Academy of Accounting Historian, 10(1), 1-23. Retrieved from https://egrove.olemiss.edu/aah journal/vol10/iss1/1

Sharpe, I. G., \& Walker, R. G. (1975). Asset Revaluations and Stock Market Prices. Journal of Accounting Research, 13(2), 293-310. https://doi.org/10.2307/2490366

Song, C. J., Thomas, W. B., \& Yi, H. (2010). Value relevance of FAS No. 157 Fair Value hierarchy information and the impact of corporate governance mechanisms. Accounting Review, 85(4), 1375-1410. https://doi.org/10.2308/accr.2010.85.4.1375

Song, X. (2015). Value Relevance of Fair Values-Empirical Evidence of the Impact of Market Volatility. Accounting Perspectives, 14(2), 91-116. https://doi.org/10.1111/1911$\underline{3838.12045}$

Sundgren, S., Mäki, J., \& Somoza-López, A. (2018). Analyst Coverage, Market Liquidity, and Disclosure Quality: A Study of Fair-value Disclosures by European Real Estate Companies Under IAS 40 and IFRS 13. International Journal of Accounting, 53(1), 54-75. https://doi.org/10.1016/j.intacc.2018.02.003

Vergauwe, S., \& Gaeremynck, A. (2019). Do measurement-related fair value disclosures affect information asymmetry? Accounting and Business Research, 49(1), 68-94. https://doi.org/10.1080/00014788.2018.1434608 